\title{
O Sacramento do Matrimônio: alguns desafios pastorais atuais
}

\author{
Orientador: Prof. Abimar Oliveira de Moraes
}

Pesquisadora: Lucimar Almeida de Souza

\section{Fonte:CNPq}

\section{Introdução}

Nesta pesquisa tentamos apresentar alguns desafios para a pastoral do sacramento do matrimônio na atualidade. Sabemos que o matrimônio é uma instituição natural que deriva da própria existência humana ou, se quisermos, uma instituição natural. Contudo, para a teologia cristã, em chave sacramental, tal instituição está fundada no projeto de Deus que cria na diversidade e complementariedade entre homem e mulher e que, em Jesus Cristo, confere ao matrimônio uma dignidade de processo de serviço e santificação da pessoa humana, à luz das características e exigências da "Nova Lei".

Por isso, o casal, na diferença e na complementaridade do ser homem e do ser mulher, torna-se sinal permanente e indissolúvel da Aliança que Deus selou com todo gênero humano, no seu Cristo. Esta é a base da sacramentalidade e vivência matrimonial na experiência cristã, dos primórdios até hoje.

O sacramento do matrimônio, portanto, é uma realidade complexa, pois abarca em si as dimensões interpessoal, familiar e social e, ao mesmo tempo, as dimensões eclesial e escatológica da existência cristã. Todas essas dimensões passam por constantes transformações; por isso, cabe às comunidades cristãs a tarefa de ajudar todas as pessoas vocacionadas ao matrimônio na realização desse serviço; seja através da preparação prévia à vida matrimonial, seja através da manutenção da mesma.

A Igreja desde os seus primeiros séculos até hoje é chamada a adaptar-se às mudanças sociais e contextos culturais em que realiza a sua missão salvífica; sem, contudo, deixar de salvaguardar a sua experiência fundante que a constitui e identifica como a Igreja de Cristo. 
$\mathrm{Na}$ atualidade, são muitos os desafios pastorais apresentados ao sacramento do matrimônio. No contexto da evangelização e transmissão da fé atual, destacamos como tantos candidatos ao matrimônio precisam conhecer (ou redescobrir) a sua grandeza, compreender as raízes teológicas da sua irrevogabilidade. Ao mesmo tempo, compete à teologia pastoral assegurar a vivência dos valores imprescindíveis do matrimônio, numa sociedade que tende a questionar a sua natureza, importância e que, em muitos ambientes, reduziu-o a um rito social, desvinculados dos seus basilares aspectos teológicos (unidade, dissolubilidade, fidelidade). Em vista disso, os desafios pastorais são amplos e complexos.

\section{Objetivos}

O objetivo da pesquisa era apresentar o sacramento do matrimônio, no que ele tem de específico: o "sim" dos esposos, como tradução concreto do "sim" dado ao Deus de Jesus Cristo. Para tanto, escolhemos analisar como a atual pastoral do sacramento do matrimônio reflete mais (ou menos) a doutrina dogmática acerca do matrimônio.

Objetivamos, em nossa pesquisa, também, ampliar nosso conhecimento acerca da prática dos agentes de pastoral matrimonial. Notamos como tal prática está pouco fundada sobre a teologia do matrimônio. Apresentando-nos, assim, o desafio de produzir itinerários educativos para uma melhor formação desses agentes e, através deles, daqueles que buscam a experiência sacramental do matrimônio.

Por fim, pudemos perceber como os desafios pastorais sobre o sacramento do matrimônio, no contexto atual, são uma realidade complexa e desafiadora para a evangelização e transmissão da fé às novas gerações. 